\title{
DECREASING LEVELS OF BIOLOGICAL OXYGEN DEMAND (BOD) AND AMMONIA USING MULTI SOIL LAYERING (MSL) PROCESS IN ALCOHOL TRADITIONAL WASTEWATER
}

\section{Penurunan Kadar Biological Oxygen Demand (BOD) dan Amonia Menggunakan Proses Multi Soil Layering (MSL) Pada Limbah Cair Alkohol Tradisional}

\author{
Brilliant Maulana Amara ${ }^{1 *}$ dan Siti Fatimah ${ }^{2}$ \\ ${ }^{1}$ Prodi Teknik Kimia, Fakultas Teknik, Universitas Muhammadiyah Surakarta \\ 2.Prodi Teknik Kimia, Fakultas Teknik, Universitas Muhammadiyah Surakarta \\ *email: criztianobrilliant@gmail.com, sf120@ums.ac.id
}

Received : 27 Juni 2020; Accepted : 24 Juli 2020; Publish : Juli 2020

\begin{abstract}
Alcohol can be made traditionally, where in Bekonang Sukoharjo alcohol wastewater is discharged into free water, high levels of Biochemical Oxygen Demand (BOD) and Ammonia pollute the environment. BOD is a technique for characterizing the amount of dissolved oxygen required by microorganisms by the degradation of organic compound under aerobic conditions. Ammonia contained in alcohol waste can oxidize organic matter in water. Multi Soil Layering (MSL) is a process to improve soil quality in organic wastewater treatment, the MSL method is a wastewater treatment system formed by the arrangement of materials such as zeolite, soil/sand, charcoal and others. The factors examined in this study regarding the use of soil and sand material compiled in MSL. With MSL method can reducing BOD levels by $43.76 \%$ using MSL contain soil mixed with activated carbon and $56.26 \%$ using MSL contain river sand, while Ammonia levels fell by $24 \%$ and $25 \%$ from $30 \%$.
\end{abstract}

Keywords: Alcohol, MSL, BOD, Ammonia, Wastewater

\begin{abstract}
ABSTRAK
Alkohol dapat dibuat secara tradisional, di mana di Bekonang Sukoharjo limbah alkohol dibuang ke air bebas, tingkat tinggi dari Biochemical Oxygen Demand (BOD) dan Amonia membuat lingkungan tercemar. BOD adalah teknik untuk mengkarakterisasi jumlah oksigen terlarut yang dibutuhkan oleh mikroorganisme melalui degradasi senyawa organik dalam kondisi aerobik.. Amonia yang terkandung dalam limbah alkohol dapat mengoksidasi bahan organik dalam air. Multi Soil Layering (MSL) adalah proses untuk menaikkan kualitas tanah dalam pengolahan air limbah organik, metode MSL merupakan sistem pengolahan air limbah yang dibentuk susunan material seperti zeolite, tanah/pasir, arang dan lainnya. Faktor yang diteliti dalam penelitian ini tentang penggunaan material tanah dan pasir yang disusun di MSL. Dengan metode MSL bisa mengurangi kadar BOD sebanyak 43.76\% menggunakan MSL yang berisi tanah yang dicampur carbon aktif dan 56.26\% menggunakan MSL yang berisi pasir sungai, sedangkan kadar Ammonia turun sebanyak 24\% dan 25\% dari $30 \%$.
\end{abstract}

Kata kunci: Alkohol, MSL, BOD, Ammonia, Air Limbah 


\section{INTRODUCTION}

The alcohol industry or commonly in their call as ciu , located in Sentul Hamlet, Bekonang Village, Mojolaban Subdistrict, Sukoharjo Regency, is an industry that has not obtained an industrial permit. Alcohol that produced there still uses traditional methods. Alcohol is commonly determined to be the chemical component alcohol or ethyl alcohol [1].

The alcohol manufacturing industry is a home-scale industry so that the processing of the waste has not been properly processed. The waste is thrown away in free water and only a little is processed in the WWTP (Waste Treatment Plant) which does not function so that the smell of waste disturbs the surrounding environment. Not only smells, alcohol waste or the usual local residents call it badek also results in agricultural products whose commodities are rice in the surrounding environment can not grow optimally even up to crop failure. The refined waste has biological oxygen requirements (BOD), chemical oxygen requirements (COD), and BOD / COD ratios and very high amounts of inorganic substances such as nitrogen, potassium, phosphate, calcium, sulfate. These compounds that have toxic antioxidant properties harm many microorganisms present in the wastewater treatment process. Alcohol waste are acidic, have a brown colour, have a high content of organic substances and contain large amount of dark brown coloured molasses wastewater (MWW). The highly colored waste component can block sunlight from freshwater waters, so that the dissolved oxygen concentration and photosynthetic activity decrease which affects aquatic life. [2].

Alcohol industry wastewater in Bekonang village, Mojolaban, Sukoharjo has BOD levels of 55,000 mg / 1, COD levels of $170,316 \mathrm{mg} / 1$ and TSS levels of $5640 \mathrm{mg} / 1$. These results are above the standard quality of liquid waste determined by the government. If the waste has a high BOD and
COD content it meets the characteristics of high organic liquid waste[3]

BOD is a technique for characterizing the amount of dissolved oxygen required by microorganisms under aerobic conditions by the degradation of organic compound. Empirical analysis that tries to detect the entire microbiological process that actually occurs in water or called BOD where the BOD number is the amount of oxygen required by microorganisms to oxidize some of the dissolved and suspended organic substances in the water. To determine pollutants due to wastewater, or wastewater from residents or industry, BOD analysis can be used, and to design biological treatment systems for polluted water. The decomposition of organic matter is a natural event, if a water is polluted by organic matter, bacteria can deplete dissolved oxygen in the water during the oxidation process which can result in the death of aquatic organisms such as fish, and the condition becomes anaerobic and can cause foul odors in the water. [5]

Ammonia (NH3) is an alkaline gas that is colorless, lighter than air and has a distinctive aroma. Usually ammonia is found in the form of a gas with a characteristic pungent odor. Ammonia including caustic compounds and harmful to health. Contact with concentrated ammonia gas causes lung damage until death [6]. Ammonia is also a factor in water pollution in excess, $\mathrm{NH}$ ammonias are nitrogen compounds that become NH. At low pH ammonia is called ammonium. Ammonia in surface water from urine and feces is also from the oxidation of microbiological organic matter $(\mathrm{HaObCcNa})$, which comes from natural water or industrial and resident wastewater. [7].

So in this study we try to find out the effectiveness of the multi-layer soil (MSL) method of the material composition. Multi Soil Layering (MSL) is a technique to increase the qualityof soil in organic wastewater. Waste recycling and management have been used soil as a biological, physical, and chemical system. Soil is also useful as a medium for plant 
growth as well as for disposal of animal, human and industrial waste. The MSL technique uses a carbon source system from zeolite, charcoal and soil arranged like bricks as a source of oxygen aeration pipes. [4].

A multi soil layering (MSL) process has been developed and studied to improve soil quality for complete purification. Municipal wastewater, livestock wastewater and polluted river water treatment have been reported to be treated efficiently using MSL technique [8]. It has proven that the MSL method is a very efficient method for wastewater treatment in tropical and temperate climatic conditions. However, no previous studies have tested this technology under dry climates, characterized by high levels of evaporation, temperature fluctuations, and a long dry season. Scaling up this technology must be adopted properly based on the local conditions of rural areas, taking into account highly concentrated wastewater and climatic conditions [9].

The MSL system is one of the alternative technologies for central wastewater treatment in developing countries. Efficient and natural techniques are simple with low-cost solutions that are widely used where the MSL system is contained by two layers, a permeable layer interspersed with a mixed layer of soil. The permeable layer consists of gravel or perlite, and zeolite, the soil mixture layer consists of soil, hemp or sawdust, iron particles, charcoal or alternative materials. This structure reduces the risk of clogging and keeps water permeability high [10].

If the research conducted by Irmanto et al [6], uses variations in the speed of filling, we try to do research by focusing on the composition of the material in MSL.

\section{MATERIALS AND METHODS}

This research was conducted by designing 2 MSL system models, where the material composition in this system is almost the same, the only difference is the use of sand and soil in the composition of each MSL model. We want to know which is more effective

\section{Materials}

The material used is alcohol wastewater as much as $10 \mathrm{ml}$, then diluted 500X to make it easier when analyzing BOD and Ammonia levels, the tools used are 2 models of the MSL system using a $1.5 \mathrm{~L}$ bottle that has cut the bottom by $2 \mathrm{~cm}$, with the composition of the absorbent material arranged. The design of MSL systems equipment consists of :

a. Model 1: gravel, charcoal, zeolite sand, coarse cotton, a mixture of soil with activated carbon, and fine cotton.

b. Model 2: gravel, charcoal, zeolite sand, coarse cotton, river sand, and fine cotton shown on figure 1 and figure 2.

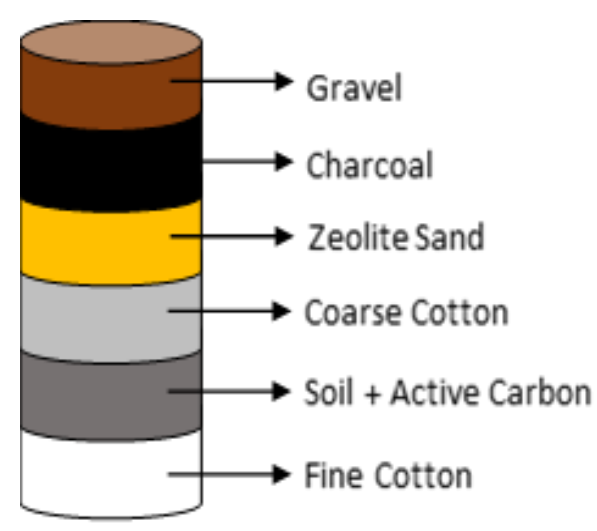

Figure 1. Model 1

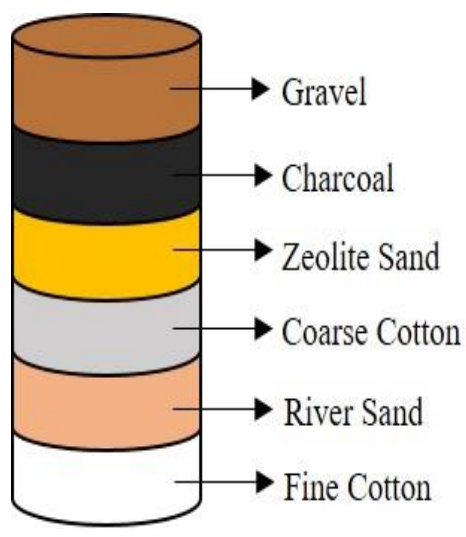

Figure 2. Model 2 
How to calculate BOD levels :

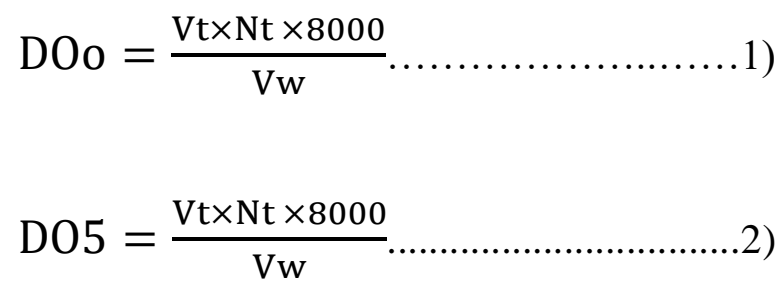

$B O D 5=$

$\left.\frac{(\text { DOo } S 1-D O 5 S 1)-(D O o B S 1-D O 5 B S 1) \times(1-P)}{P} \ldots .3\right)$

Vt : Volume titration of Thiosulfate

$\mathrm{Nt} \quad$ : N of Thiosulfate

Vw : Volume Winkler Bottle

S : Sample

BS : Blanko Sample

P : Dilution Volume

How to calculate ammonia levels :

Ammonia level $=\mathrm{C} \times \mathrm{fp}$

$\mathrm{C}=$ The level obtained from the measurement results, $(\mathrm{mg} / \mathrm{l})$

$\mathrm{Fp}=$ Dilute factor

\section{Procedure}

Liquid alcohol waste taken directly from the temporary reservoir as much as 10 $\mathrm{ml}$ and then diluted 500X. The diluted alcohol liquid waste sample is divided into 3 , for sample 0 , sample 1 and sample 2 . Sample 0 is directly analyzed for BOD and ammonia levels while sample 1 is poured into Model MSL 1 and then the liquid that comes out of the system is collected and analyzed BOD and Ammonia levels. Likewise with sample 2, it was poured into Model MSL 2 and then the liquid that came out of the system was collected and analyzed the levels of BOD and Ammonia in the laboratory

\section{RESULTS AND DISCUSSION}

In the research that has been done, the results show that the Multi Soil Layer (MSL) system has an influence on the reduction and changes in BOD levels and ammonia levels in alcohol liquid waste. The levels of BOD and ammonia obtained are as in the table below:

Table 1. Results data of $\mathrm{BOD}_{5}$ levels

\begin{tabular}{cc}
\hline Sample & Level $\left(\mathbf{~ m g ~ O}_{2} / \mathbf{l}\right)$ \\
\hline $\begin{array}{c}\text { Sample 0 (Do not pass } \\
\text { through the filter) }\end{array}$ & 51209.6 \\
\hline Sample 1 & 22409.6 \\
\hline Sample 2 & 28809.6 \\
\hline
\end{tabular}

Table 2. Results data of Ammonia levels

\begin{tabular}{cc}
\hline Sample & Level ( \% ) \\
\hline Sample 0 & 30 \\
\hline Sample 1 & 24 \\
\hline Sample 2 & 25 \\
\hline
\end{tabular}

The data in the table was obtained after passing the BOD and Ammonia analysis, which is affected by the adsorbent composition in each system. Unlike BOD, ammonia levels are not significant, this can occur because microorganisms in the filter have not been fully formed so that ammonia degradation is less than optimal.

The results obtained after MSL were satisfactory, where BOD levels from $51,209.6 \mathrm{mgO}_{2} / \mathrm{L}$ fell to $22409.6 \mathrm{mgO}_{2} / \mathrm{L}$ and $28,809.6 \mathrm{mgO}_{2} / \mathrm{L}$, this could be due to the influence in the MSL systems ie the soil where in the soil there are microorganisms that can degrade alcohol wastewater. However, this result cannot be said to be successful because it is still far from the level permitted by the existing law on liquid waste. Accordance with the Regional Regulation of Central Java Province No 5 of 2012 in table 3 : 
Table 3. Data on liquid waste quality standard parameters

\begin{tabular}{cccc}
\hline Parameter & $\begin{array}{c}\text { Maximum } \\
\text { Levels } \\
(\mathbf{m g} / \mathbf{L})\end{array}$ & \multicolumn{2}{c}{$\begin{array}{c}\text { Maximum } \\
\text { Pollution Load } \\
(\mathbf{k g} / \text { ton })\end{array}$} \\
\cline { 3 - 4 } & & MSG & GA \\
\hline BOD5 & 80 & 5.6 & 2.8 \\
\hline COD & 150 & 10.5 & 5.25 \\
\hline TSS & 100 & 7 & 3.5 \\
\hline pH & & $6.0-9.0$ & \\
\hline Daximum & & $\begin{array}{c}70 \\
\mathrm{~m}^{3} / \text { ton } \\
\text { product } \\
\text { MSG }\end{array}$ & $\begin{array}{c}35 \\
\mathrm{~m}^{3} / \text { ton } \\
\text { product } \\
\text { GA }\end{array}$ \\
\hline
\end{tabular}

The results we obtained in this study are very high, even after processing is still very high, although the effectiveness of the reduction has reached $56.26 \%$ for samples treated using model 2 with river sand content and $43.76 \%$ for samples processed using model 1 with soil mixed with carbon active, but still produces a very high problem. For the ammonia level itself from sample 0 which has not treatment, it was found that its effectiveness was $30 \%$ and after treatment the results were not much different, only decreased to $24 \%$ for sample 1 and $25 \%$ for sample 2 . The use of river sand is more optimal than soil mixed with activated carbon, this is possible because river sand naturally contains more microorganisms so that organic matter contained in alcohol waste is more degraded by microorganisms present in river sand than soil mixed with activated carbon

This decrease can occur due to the decrease in the levels of organic matter in the process of purifying wastewater divided into two main stages. The decrease in organic matter in the form of particles and colloids in the first stage and will be followed by a decrease in organic matter in the form of a solution in the second stage. Decreasing levels of organic substances in the form of particles and colloids takes place relatively quickly and is physical in nature that depends on the chemical and physical characteristics of the organic substances [6].

\section{CONCLUSION}

Based on the results of research and discussion, the following conclusions are obtained:

1. The Multi Soil Layering (MSL) method is effective in reducing BOD and Ammonia levels but is less effective in reducing BOD and Ammonia levels of alcohol waste in Bekonang Sukoharjo.

2. After being passed through the MSL system the BOD level which previously was 51,209.6 $\mathrm{mgO} 2 / \mathrm{L}$ decreased to $22,409.6 \mathrm{mgO} 2 / \mathrm{L}$ for sample 1 and $28,809.6 \mathrm{mgO} 2 / \mathrm{L}$ for sample 2 and Ammonia level from $30 \%$ decreased to $24 \%$ in sample 1 and $25 \%$ in sample 2 , this difference occurs because of differences in the composition of the material in MSL that affects.

3 . The use of river sand is more effective $12.5 \%$ compared to mixed soil with activated carbon

\section{REFERENCE}

[1]. de Vasconcelos, J. N. (2015). Ethanol Fermentation. Sugarcane: Agricultural Production, Bioenergy and Ethanol, 311-340. https://doi.org/10.1016/B9780-12-802239-9.00015-3

[2]. Patel, S., \& Durgavati Vishwavidyalaya, R. (2018). Treatment of Distillery Waste Water: A Review. 10(1), 117-139.

[3]. Karina Nurcahyani A, \& Utami; Budi. (2007). Pengolahan Limbah Cair Industri Alkohol Bekonang Menggunakan Proses Fermentasi. 112116.

[4]. Alaerts, G. \& Santika, S. S. (1987). Metoda Penelitian Air. Surabaya: Usaha Nasional. 
[5]. Satmoko, Y. (2010). Kondisi Kualitas Air Sungai Ciliwung Di Wilayah Dki Jakarta Ditinjau Dari Parameter Organik, Amoniak, Fosfat, Deterjen Dan Bakteri Coli. Jurnal Air Indonesia, 6(1), 34-42. http://ejurnal.bppt.go.id/index.php/JAI/ar ticle/view/2452/2063

[6]. Irmanto, Suyata, D., \& Zusfahair. (2012). OPTIMASI PENURUNAN COD, $B O D, \quad D A N$ TSS LIMBAH CAIR INDUSTRI ETANOL (vinasse) PSA PALIMANAN DENGAN METODE MULTI SOIL LAYERING (MSL). 131141.

[7]. Chen, X., Luo, A. C., Sato, K., Wakatsuki, T., \& Masunaga, T. (2009). An introduction of a multi-soil-layering system: A novel green technology for wastewater treatment in rural areas. Water and Environment Journal, 23(4), 255-262. https://doi.org/10.1111/j.17476593.2008.00143.x

[8]. Latrach, L., Ouazzani, N., Hejjaj, A., Mahi, M., Masunaga, T., \& Mandi, L. (2018). Two-stage vertical flow multisoil-layering (MSL) technology for efficient removal of coliforms and human pathogens from domestic wastewater in rural areas under arid climate. International Journal of Hygiene and Environmental Health, 221(1), 64-80. https://doi.org/10.1016/j.ijheh.2017.10.0 04

[9]. Latrach, L., Ouazzani, N., Masunaga, T., Hejjaj, A., Bouhoum, K., Mahi, M., \& Mandi, L. (2016). Domestic wastewater disinfection by combined treatment using multi-soil-layering system and sand filters (MSL-SF): A laboratory pilot study. Ecological Engineering, 91, 294301.

https://doi.org/10.1016/j.ecoleng.2016.0 2.036

[10]. Zein, R., Suhaili, R., Novrian, H.,
Ningsih, S., Novita, L., Swesty, N., \& Pardi, H. (2017). Research Journal of Pharmaceutical , Biological and Chemical Sciences Multi Soil Layering ( MSL ) System for Treatment of Tofu Industry Wastewater . 8(675), 675-682. 